\title{
STUDY OF THE STEEL HEAT TREATMENT MODE FOR THE PURPOSE OF INCREASING THE EFFICIENCY OF ULTRASONIC CONTROL
}

\author{
${ }^{1}$ Andrey KURBATOV, 'Julia AVERINA, ${ }^{1}$ Evgenii KUZIN, ${ }^{1}$ Victoria TSEVKOVA, \\ ${ }^{1}$ Nadezhda MOISEEVA \\ 'D. Mendeleev University of Chemical Technology of Russia, 125047, Moscow, Miusskaya pl. 9, Russia, \\ andreikurbatov@yandex.ru
}

https://doi.org/10.37904/metal.2020.3518

\begin{abstract}
More and more attention is being paid to non-destructive testing of connecting elements. Currently, ultrasound control is widely used. A prerequisite for an effective and reliable process of ultrasonic testing is the grain size of the analysed metal. One option for influencing non-grain size of a steel part is to vary the heat treatment and tempering conditions. As part of the study, an assessment was made of the heat treatment modes of steel parts for grain size. It has been established that by changing the heat treatment and tempering regime it is possible to obtain grain with a size of 3-5 points. The optimal mode of the heat treatment process was selected, which allows to obtain the minimum grain size of $4-5$ balls that is acceptable for ultrasonic testing.
\end{abstract}

Keywords: Metallurgy, steel, properties, applications, testing methods

\section{INTRODUCTION}

Non-destructive testing processes for connecting steel elements are currently receiving increasing attention. Failure of the connecting element under load can lead to human casualties. In the best case, a breakdown of the connecting element destroys the structure, and long-term repair of the structure leads to high economic costs, both due to the need to replace damaged parts of the structure (capital costs), and indirectly due to equipment downtime [1-5].

An essential condition for the effective and long-term operation of the connecting element is a guaranteed tightness, so it is not possible to remove the connecting element (bolt, rivet) without stopping the operation of the structure or disassembling it.

In order to increase the service life of the connecting elements and the entire structure as a whole, an integral part of the operation of any node is the timely detection of defects and the rapid replacement of the connecting element, until the critical level of deformation and breakage of the node is accumulated.

There are many control systems for connecting elements, but most of them require the extraction of parts from the assembly, which leads to forced production downtime, significantly complicating the control process. The number of non-destructive testing methods is very limited and is represented mainly by physical methods (ultrasound, gamma defectoscopy, etc.) [6,7].

Currently, for the timely monitoring of various metal structures, ultrasonic testing methods are used. Ultrasonic control is used to check the condition of gas and water pipes, quality control of the seam when welding metal or polypropylene parts. The use of the ultrasonic testing method allows you to quickly assess the state of the structure during its operation. To use the method of ultrasonic testing in the process of evaluating the axial stress of the connecting elements, there is a prerequisite that guarantees the reliability and reliability of the data. For ultrasonic testing processes, the grain size of the steel should correspond to the specified parameters 
according to the technological documentation. It should be noted that this parameter varies depending on the type of element being monitored $[8,9]$.

According to the results of preliminary experiments, it was found that in order to achieve maximum efficiency of ultrasonic testing of bolted connecting elements made of austenitic-martensitic steel grade 07XI6H6, grain size should be at least 5 points. An increase in grain size above this figure leads to a decrease in toughness and an increase in the cold brittleness threshold [10].

The main objective of this work is the selection of the heat treatment mode of austenitic-martensitic steel grade $07 X 16 \mathrm{H} 6$ with the goal of obtaining grain size of 5 points. The data obtained will allow us to apply the process of non-destructive ultrasonic testing of bolted and riveted connecting elements made of this steel.

\section{METODS OF ANALYSES}

The grain size was determined by microstructural analysis. The test sample was pre-treated with wet grinding and polishing. The pre-ground sample was subjected to etching, as a result of which defects are formed on the surface of the micro-section, which reliably determine the microstructure of the alloy [8]. In order to increase the efficiency of grain detection, the samples that passed the etching process were subjected to isothermal exposure at a temperature of $750^{\circ} \mathrm{C}$ for 1 hour.

The surface condition was studied using a Metam PB-21-2 metallographic microscope. In the process of metallographic analysis, the presence of non-metallic inclusions and the preliminary grain size of the metal were determined. The exact grain size was determined by comparing microphotographs (100 times) of the grain in the sample of the steel under study and a similar photograph of the reference sample.

\section{METODS OF EXPERIMENTS}

For steel sections cast from steel grade $07 \mathrm{XI6H6}$ (chrome-nickel), the following heat treatments were performed as it from Table 1 follows, where are also summarised grain sizes of the austenitic-martensitic steel of the grade $07 \mathrm{XI} 6 \mathrm{H} 6$ in dependence on conditions of the heat treatment process. Ggrain sizes at the same magnification are demonstrated in Figure 1.

Table 1 Effect of heat treatment on grain size

\begin{tabular}{|c|c|c|c|}
\hline $\begin{array}{c}\text { Sample } \\
\text { No. }\end{array}$ & Heat treatment mode & $\begin{array}{c}\text { Grain point at } \\
\times 100\end{array}$ & $\begin{array}{l}\text { Figure } \\
\text { number }\end{array}$ \\
\hline 1 & $1200^{\circ} \mathrm{C} / 10$ hours $\rightarrow 750^{\circ} \mathrm{C} / 1$ hour/water & $0-1$ & \\
\hline 2 & $\begin{array}{c}1200^{\circ} \mathrm{C} / 10 \text { hours } / \text { water }+780^{\circ} \mathrm{C} / 1.5 \text { hours }+680^{\circ} \mathrm{C} / 1.5 \text { hours }+1000 \\
{ }^{\circ} \mathrm{C} / 1 \text { hour } / \text { water }+780^{\circ} \mathrm{C} / 1.5 \text { hours }+680^{\circ} \mathrm{C} / 1.5 \text { hours }+1000^{\circ} \mathrm{C} / 1 \\
\text { hour } \rightarrow 750^{\circ} \mathrm{C} / 1 \text { hour } / \text { water }\end{array}$ & $4-5$ & Figure1 B \\
\hline 3 & $\begin{array}{c}1200{ }^{\circ} \mathrm{C} / 10 \text { hours } / \text { water }+780{ }^{\circ} \mathrm{C} / 1.5 \text { hours }+680^{\circ} \mathrm{C} / 1.5 \text { hours }+1000 \\
{ }^{\circ} \mathrm{C} / 1 \text { hour/water }+(-70) / 2 \text { hours }+650^{\circ} \mathrm{C} / 2 \text { hours } / \text { water }+650{ }^{\circ} \mathrm{C} / 2 \\
\text { hours/water }+1000{ }^{\circ} \mathrm{C} / 1 \text { hour } \rightarrow 750^{\circ} \mathrm{C} / 1 \text { hour } / \text { water }\end{array}$ & 4 & Figure1 C \\
\hline 4 & $\begin{array}{c}1200^{\circ} \mathrm{C} / 10 \text { hours } / \text { water }+780^{\circ} \mathrm{C} / 1.5 \text { hours, }+680^{\circ} \mathrm{C} / 1.5 \text { hours, }+625 \\
{ }^{\circ} \mathrm{C} / 2 \text { hours/water }+625^{\circ} \mathrm{C} / 2 \text { hours/water }+1000^{\circ} \mathrm{C} / 1 \text { hour } \rightarrow 750^{\circ} \mathrm{C} / 1 \\
\text { hour/water }\end{array}$ & 3-4 & Figure $1 \mathrm{D}$ \\
\hline 5 & $\begin{array}{c}1200{ }^{\circ} \mathrm{C} / 10 \text { hours } / \text { water }+780^{\circ} \mathrm{C} / 1.5 \text { hours, }+680^{\circ} \mathrm{C} / 1.5 \text { hours, }+ \\
1000^{\circ} \mathrm{C} / 1 \text { hour } / \text { water }+(-70) / 2 \text { hours }+780^{\circ} \mathrm{C} / 1.5 \text { hours, }+680^{\circ} \mathrm{C} / 1.5 \\
\text { hours, }+7800^{\circ} \mathrm{C} / 1.5 \text { hours }+680^{\circ} \mathrm{C} / 1.5 \text { hours }+1000{ }^{\circ} \mathrm{C} / 1 \text { hour } \rightarrow 750 \\
{ }^{\circ} \mathrm{C} / 1 \text { hour } / \text { water }\end{array}$ & 4 & Figure1 E \\
\hline
\end{tabular}


Modes 3, 4 and 5 (respectively, Figure $\mathbf{1}$ C, D and E) allow to get grain with a size of up to 4 points, while mode 2 allows to get grain with a size of $4-5$ points. Modes 3 - 5 can be used to obtain grains of other sizes.

A

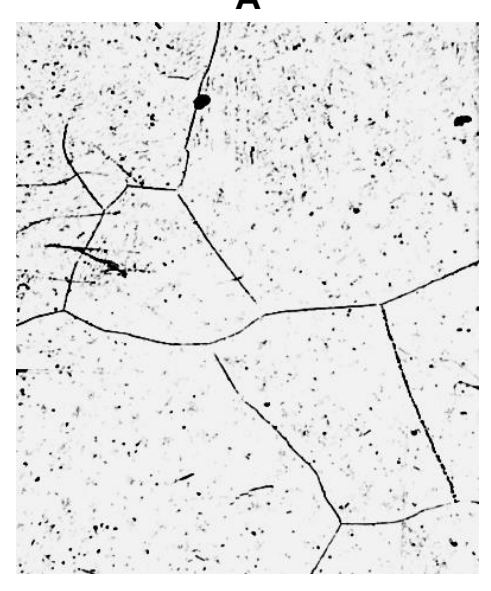

B

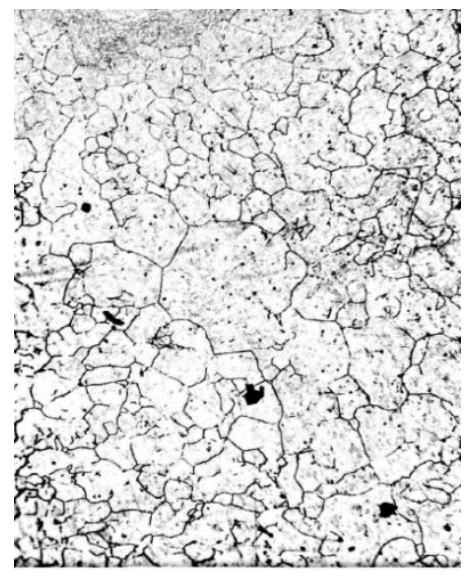

D
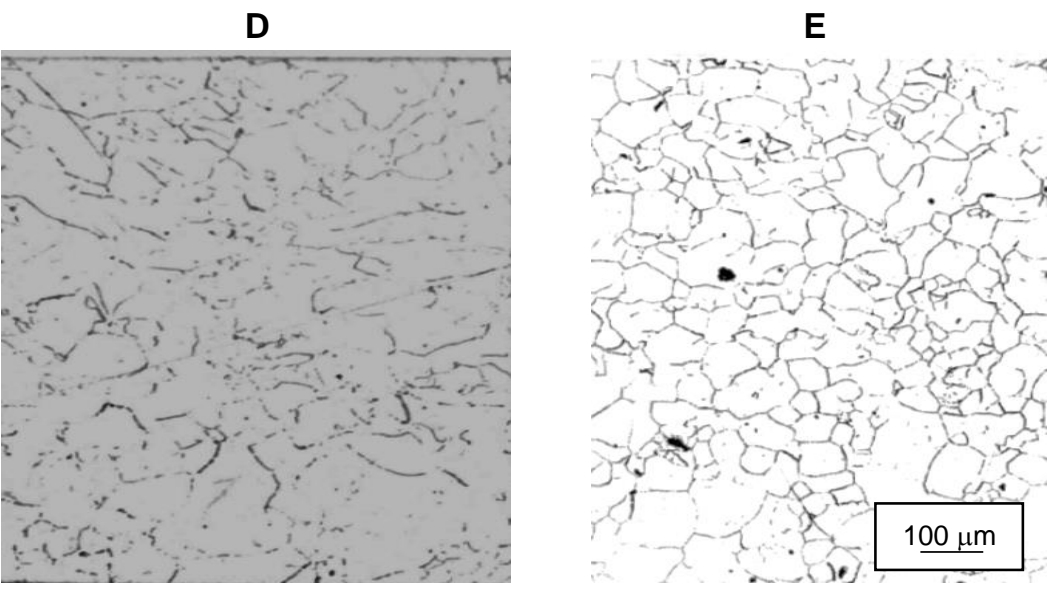

Figure 1 Microstructures of steel grade $07 \times 16 \mathrm{H} 6$ after different heat treatment modes at the same magnification; grain sizes are summarised in Table 1

\section{CONCLUSION}

As a result of a number of experiments, a heat treatment regime was developed for austenitic-martensitic steel of the grade $07 \mathrm{XI} 6 \mathrm{H} 6$, which allows obtain grain with a size of $4-5$ points, which will effectively determine the magnitude of the axial stress after tightening the bolts in the process of ultrasonic non-destructive testing.

To obtain a given grain size, heat treatment of steel should be carried out under the following conditions: $1200{ }^{\circ} \mathrm{C}, 10$ hours, water cooling, then $780^{\circ} \mathrm{C}, 1.5$ hours, air cooling; $680^{\circ} \mathrm{C}, 1.5$ hours, air cooling; $1000^{\circ} \mathrm{C}$, 1 hour, water cooling; $780^{\circ} \mathrm{C}, 1.5$ hours, air cooling; $680^{\circ} \mathrm{C}, 1.5$ hours, air cooling; $1000{ }^{\circ} \mathrm{C}, 1$ hour; $750{ }^{\circ} \mathrm{C}$, 1 hour, water cooling. If it is necessary to obtain finer grain, it is possible to use heat treatment modes $3-5$ (Table 1).

Based on the data obtained as a result of the study, a heat treatment process has been developed for parts that can produce grain of a given size (4-5 points) and simplify the system of ultrasonic monitoring of the state of the connecting elements, which will further reduce equipment downtime and prevent the risk of accidental fracture of the connection. 


\section{ACKNOWLEDGEMENTS}

This work was supported by the D. Mendeleev University of Chemical Technology of Russia through the Internal Bridging Grants for Young Science Educators Contest, proposal no. K-2020-015.

\section{REFERENCES}

[1] MIRCHEV. Y., CHUKACHEV, P., MIHOVSKI. M. Methods for evaluation of mechanical stress condition of materials. Matec. Web of Conferences. 2018, vol. 145, 05008.

[2] IVANOVA Y., TELBIZOV, G. The possibilities for stress evaluation by using the ultrasonic surface waves. Sci. Announce Sof. Sci. Tech. Union Mech. Eng. 2008, vol. 105, no. 2, pp. 185 -190. (In Bulgarian)

[3] KURASHKIN, V.M.K. On the method of ultrasonic control of mechanical stresses. Zavodskaya Laboratroiya. Diagnostika Materialov. 2018, vol. 84, no. 7, pp. 62-66 2018.

[4] MAYRHOFER A., HARTL F., RORHOFER A., STOLL K. Monitoring the status of equipment in steel production. Ferrous metals. 2018, no. 9, pp. 28-33.

[5] AVERINA, Y.M., NAUMKINA, V.A., NEDASHKOVSKY, K.I. Metallographic research into the quality of $\mathrm{x} 15 \mathrm{n} 27 \mathrm{t3mr}-\mathrm{vd}$ steel wire (ep700-vd). Journal of Physics. 2019, no. 1348, pp. 1-3.

[6] ZHU Y. et al. Ultrasonic testing system design for defect visualization of inhomogeneous multi-layered pipes. $S N$ Applied Sciences. 2019, vol. 1, no. 12, pp. 15-23.

[7] SHARMA A., SINHA A. K. Ultrasonic testing for mechanical engineering domain: present and future perspective. International Journal of Research in Industrial Engineering. 2018, vol. 7, no. 2, pp. 243-253.

[8] GOST 14782-86 "Welded joints. Ultrasonic methods".

[9] VAHRAMYAN T.A., VASILENKO O.A., GRIGORYAN N.S., ZHUKOV A.P., MAZUROVA D.V. Materials Science. Technology of structural materials. Moscow: DI. Mendeleev, 2009.

[10] LAKHTINYU.M., LEONTIEV V.P. Materials Science. Moscow: Mechanical Engineering, 1990.

[11] AVERINAYU.M., KALYAKINA G.E., NAUMKINA V.A., SAFAROVA I.S. A method for controlling the quality of metal alloys by determining their chemical composition. Chemical industry today. 2018. no. 4, pp. 47-55. 